\title{
Exploration on the Reform of College English Teaching Model in the Era of Big Data
}

\author{
Li Yang ${ }^{1, *}$ \\ ${ }^{1}$ Hunan Institute of Traffic Engineering, Hengyang, Hunan 421000, China \\ ${ }^{*}$ Corresponding author. Email: 3132661772@qq.com
}

\begin{abstract}
In the current era of big data, the teaching methods and concepts of college English have undergone great changes. Therefore, it is necessary to make full use of the characteristics of big data technology in the collection and integration of information and other aspects to build a new three-dimensional teaching model in order to effectively promote the reform and development of college English teaching. However, in the current era of big data, China's college English teaching model is relatively backward, which has a great impact on the actual teaching level and efficiency. Therefore, teachers need to continuously optimize and innovate the current teaching model when teaching, so as to contribute to the significant improvement of teaching effectiveness. In response to this situation, this article elaborates and studies the meaning of big data, the status quo of the problems faced by college English teaching in the era of big data, as well as the corresponding reform measures, hoping to provide some referential opinions for relevant teachers.
\end{abstract}

Keywords: Big data era, College English, Teaching model, Current reform.

\section{INTRODUCTION}

Innovating the teaching model of college English has played a vital role in the reform of college English teaching, helping to enhance students' initiative in learning, and improve the actual teaching level and quality. In the process of innovating the English model of colleges and universities, teachers need to make full use of big data technology when constructing informatization teaching, so as to further dig out high-quality information, well meet the specific needs of students, build a novel teaching model, and effectively promote the construction and development of English educational informatization.

\section{THE CONNOTATION OF BIG DATA}

Big data mainly refers to diversified mass data, which is based on information technology and computer technology and formed under the reform and innovation of English. There are many representative characteristics of big data, such as faster data processing speed, and diversified data types and so on. With the continuous development of science and technology, big data technology has penetrated into people's daily lives. People not only make full use of big data, but also continuously add new data to it, which helps to integrate and evaluate people's behavioral data. Therefore, the use of big data technology can effectively realize the use, analysis, and collection of data information, which provides a favorable guarantee for people to update their concepts and innovate technologies. Thus in the development process of various industries in society, it is necessary to have a clear understanding of the effective role of data information from the perspective of big data, and to further explore the application skills of big data technology to provide a solid guarantee for the establishment of a production and operation development model based on big data. [1]. 


\section{THE BOTTLENECK OF COLLEGE ENGLISH TEACHING IN THE ERA OF BIG DATA}

\subsection{The Past Teaching Methods Can't Keep Up with the Development of the Times}

At present, most college talents in China use the past cramming method for teaching. In the process of teaching, teachers transfer knowledge to students ponderously, without considering whether students can truly master the knowledge. In addition, in the past college English teaching, teachers and students lacked effective communication, the teaching goals were not precise enough, and the teaching content was too simple and boring, and as a result, students were not focused enough in the learning process, and they were not paying enough attention to the knowledge content taught by the teacher. In the specific teaching process, some teachers paid too much attention to students' doing exercises, and often assigned much homework to students; whether the teaching effectiveness reached the standard depended on whether the students could pass the relevant examinations smoothly, and the teaching value orientation was wrong.

\subsection{The Teaching Process Fails to Properly Integrate Big Data Technology into It}

In the current era of big data, massive knowledge resources can be shared with the help of network platforms. Teachers and students can easily acquire professional knowledge in various fields, including English resources. In the past college English teaching process, teachers easily ignored the information resources currently obtained with the help of big data technology, and still focused on the use of old teaching resources. This is also the main problem faced by the efficient English at the current stage.

\subsection{Being Unable to Meet the Needs of Students}

In the past college English teaching, the traditional teaching method of one teacher facing multiple students was generally adopted. In this case, the teaching task was significantly increased, and the teacher couldn't fully consider all the personal needs of the students; in addition, teachers used the cramming method, resulting in a large gap between the teaching effect and expectations. In the era of big data, if colleges and universities still apply the past teaching methods and fail to use information media software for teaching, they will not be able to meet the subjective demands of students.

\subsection{The Teaching Content Is Too One- sided}

In today's era when big data technology is very popular, most English teachers in colleges and universities in China still take textbook knowledge as the leading factor when designing teaching goals and content, and fail to make full use of big data technology. This also shows that teachers fail to integrate big data technology in the actual teaching process, and fail to give full play to the effective role of big data technology [2]. In particular, some teachers feel that there is no specific relationship between actual teaching content and big data technology, and they fail to truly accept big data technology in their hearts, which easily leads to overly one-sided teaching content.

\section{CHANGES IN COLLEGE ENGLISH TEACHING IN THE ERA OF BIG DATA}

From the perspective of English teaching in colleges and universities, after the application of big data technology in teaching, the model and concept of teaching will change accordingly, which are shown in the following aspects.

\subsection{Changing Previous Teaching Concepts}

In the previous college English teaching, teachers dominated the classroom process, spread English cultural knowledge, interacted with students less, and the teaching method was too single. This is not conducive to the improvement of students' learning enthusiasm, and it is easy to induce teachers' loose working mood, resulting in the ineffective improvement of teaching level. Integrating big data into efficient English teaching can combine classroom teaching with extracurricular practice. The universal application of MOOCs and Micro-Courses makes students learn English knowledge without being restricted by time and place, and helps students improve their independent learning ability [3]. In the course of teaching, teachers transform into organizers of teaching activities, which can well demonstrate the leading role of students, fully mobilize students' 
subjective initiative in learning, and greatly strengthen students' English proficiency and ability.

\subsection{Using Diversified Teaching Tools for Teaching}

In today's era of big data, if teachers want to promote the reform and innovation of education, they must put science and technology in the first place. Under the premise of applying science and technology, modern education has achieved good results and has begun to progress in a diversified direction. Therefore, English teachers in colleges and universities should be proficient in modern information education technology in the teaching process. For example, teachers can use the data resource database, WeChat platform, etc., to effectively design relevant teaching activities, and combine them in a variety of ways to present the teaching content more vividly and flexibly; this method not only enriches the teaching content, but also greatly enhances the interest of classroom teaching, makes it easier to attract students' attention, and makes the teaching method more flexible and effective. For example: teachers can use multimedia facilities to set up relatively suitable virtual teaching scenes for students in combination with actual teaching content; students can use situational simulation to master the knowledge content of English proficiently, so as to have a better understanding and cognition of English knowledge.

\subsection{Changing the Way of Acquiring Teaching Resources}

In the previous English teaching in colleges and universities, the way for teachers to obtain teaching resources was mainly from textbooks, to teach textbook knowledge, to show students how to answer textbook questions, to form a set of teaching procedures, and to spread English cultural knowledge to students. In modern society, the big data technology is becoming more and more popular, making the ways and paths of obtaining information more diversified, and the speed of obtaining information has also been significantly improved. Both teachers and students can use big data technology to obtain the resource content they need from the massive data information, and achieve the purpose of resource sharing and updating in time, promoting the English resources of colleges and universities to be more diversified, and abandoning the previous model of completely relying on textbook resources. For example, in the course of listening class teaching, college English teachers can explore relevant English materials on the network platform based on the students' English listening and speaking level and their personal characteristics. And with the help of editing and typesetting, the English materials found can be turned into valuable English education resources, adding some lively and interesting atmosphere to the single and boring English class.

\section{REFORM COUNTERMEASURES OF COLLEGE ENGLISH TEACHING IN THE ERA OF BIG DATA}

\subsection{Abandoning the Previous Concept of College English Teaching}

The reform and innovation of the current college English teaching model is an inevitable path for the development of college English in the era of big data [4]. In order to improve the level and quality of English teaching in colleges and universities, it is necessary to break the old teaching concepts. In the modern information-based society, it is needed to have a variety of efficiency, such as the transmission of knowledge information and so on. According to big data, many college English teachers still adopt old teaching concepts in the actual teaching process, which makes it difficult for college English teaching to adapt to the needs of the modern information-based society. Therefore, colleges and universities need to combine big data technology to put forward some requirements for English teachers, adopt various methods to optimize and adjust the current English teaching system, and reform the teaching concepts of college English teachers in depth, so that colleges and universities can effectively realize digital and informationalized English teaching. In addition, colleges and universities need to improve the professional abilities and qualities of English teachers to help teachers apply big data technology in teaching more handily.

\subsection{Guiding Students to Change Their Own Way of Learning English}

Reforming and innovating traditional English teaching methods from the perspective of modern big data, effectively realizing teachers' diversified teaching methods, and adjusting current teaching methods will help students improve their language application ability, which is also the main criterion 
for measuring teachers' teaching level. If English teachers in colleges and universities want to improve their professional ability and work quality, they must be proficient in the operation skills of relevant advanced equipment and use diversified teaching methods to teach. For example: In the specific teaching process, teachers who use multimedia technology to teach can help attract students' attention and effectively enhance students' interest in English learning, and their teaching results are significantly higher than those of teachers who apply previous teaching methods. In today's era of big data, teachers need to use scientific and effective information methods to organically integrate students' individual needs, hobbies, characteristics and classroom content, and guide students to adopt novel learning methods to learn English knowledge. For example: To strengthen students' English vocabulary reserve, teachers can prepare some lesson-related movie clips to play in the class, effectively mobilizing students' interest in English learning, encouraging students to watch movies in classroom learning, enabling students to master more English words, and effectively improving students' English listening and speaking skills. Moreover, after the students watch the English movies, the students' language sense ability is greatly improved, which helps the students to have a further understanding of grammar, so as to achieve the purpose of using English to express flexibly and accurately.

\subsection{Improving the Efficiency of English Teaching According to the Specific Needs of Students}

In the era of big data, the most representative feature is the collection of a large amount of data information. After seeing the information, the most important thing is how to choose the data information you need from it. English teachers in colleges and universities need to guide students in the identification and selection of information, so that students can use external forces to analyze their own potential needs, further explore some potential knowledge, and find the data and information they need. There is a lot of potential information in the libraries of colleges and universities in China, such as various reference materials and so on. Institutions of higher learning can use the highquality resources in the library to encourage students to adopt a reasonable way to collect information in the library, which will help students to improve their learning effectiveness [5]. In addition, schools need to use information technology to build a good learning space, so as to effectively enhance students' enthusiasm for learning. For example, the use of online platforms for high-quality video and audio push can effectively alleviate students' learning pressure and guide students to explore the cultural charm of English.

Information sharing is very important in the process of college English teaching. From the perspective of big data, as students take the lead in information data, teachers need to give full play to the effectiveness of students. For example, teachers can encourage students to collect and sort out various types of English resources, and then use the network platform to share resources among students. The use of this sharing method between students can effectively stimulate students' ability to explore and learn spontaneously, and it is also conducive to enhancing their teamwork ability.

\subsection{Establishing a Comprehensive English Informatization Platform for Colleges and Universities}

In modern society, English teaching in colleges and universities needs to keep up with the development of the times, introduce information technology, and build a relatively complete network information platform with the help of the characteristics of big data, so as to effectively enhance students' learning initiative. As far as the network information platform for English teaching in colleges and universities is concerned, it can not only realize the sharing of English information resources, but also has a very significant effect on improving the learning efficiency of students. Therefore, colleges and universities need to integrate information technology and computer technology into the teaching of English knowledge, and build a practical and efficient English intelligent platform, so as to effectively meet the requirements of today's society for college English teaching.

\section{CONCLUSION}

In summary, the advent of the era of big data has changed the past teaching methods and further promoted the reform and innovation of college English teaching. Therefore, college English teachers must continuously enrich their professional level and innovate teaching models in the teaching process, combine big data technology with English teaching model organically, and promote the 
teaching model to develop in the direction of informatization and intellectualization, which will help improve the overall quality of teaching, improve students' learning level, and provide society and employers with more high-quality English professionals.

\section{AUTHORS' CONTRIBUTIONS} Yang.

This paper is independently completed by $\mathrm{Li}$

\section{REFERENCES}

[1] Cai Xiaohui. Reform and Innovation of College English Teaching Model Against the Background of Big Data Era [J]. Knowledge Library, 2020, No.473(01):184-184. (in Chinese)

[2] Wang Xinping. Reform and Innovation of College English Teaching Model Against the Background of Big Data Era [J]. English on Campus, 2019, No.476(36):79-80. (in Chinese)

[3] Wu Si, Yang Dongcheng. Research on College English Teaching Model Innovation and Informationization in the Era of Big Data [J]. Electronic Journal of New Education Era: Student Edition, 2019, 000(003): 1-1. (in Chinese)

[4] Xu Xuejie, Yang Chunhui. The Construction of College English Teaching Model Against the Background of Big Data $[\mathrm{J}]$. Science \& Technology Information, 2020, v.18; No.575(02):105-106. (in Chinese)

[5] Liu Xiaobo. College English Education Reform and Teaching Improvement in the Era of Big Data [J]. Knowledge Library, 2019, 000(003): P.175-176. (in Chinese) 